\title{
Spirituality and Depression with Self-Moving Trends in Adolescents: (Empirical Evidence in Yogyakarta, Indonesia)
}

\author{
Sri Setyowati ${ }^{1, *}$, Suyatno $^{2}$ \\ ${ }^{1,2}$ STIKes Surya Global Yogyakarta, Yogyakarta, 53235, Indonesia \\ ${ }^{1}$ Setyoku.sg@gmail.com* \\ * corresponding author \\ Submission date: 13 Nopember 2019, Receipt date: 20 November 2019, Publication date: 1 November 2020
}

\begin{abstract}
Indonesia is the 14th country with the highest suicide rate in the world and the 8th highest country in ASEAN. Yogyakarta is the city that places the second rank in Indonesia with the highest child and adolescent suicide rates. The purpose of this study is to analyze spirituality and depression with suicidal tendencies in adolescents in Gunung Kidul, Yogyakarta. The method used is of quantitative research using multiple regression. This study found that there is a significant relationship between depression and suicidal tendencies. This study suggests that the need for the role of counselling guidance teachers to improve their guidance and counselling as well as the role of community nurses to optimize their nursing care, especially in adolescents.
\end{abstract}

Keywords: spirituality, depression, self-moving, suicidal tendencies, adolescents.

\section{INTRODUCTION}

According to the World Health Organization (WHO) suicide is a global problem, recorded in 2015 more than 800,000 people per year die from suicide. Suicide is the second leading cause of death at the age of $15-29$ years. $75 \%$ of suicides occur in low and middle-income countries, including Indonesia. Indonesia is the 14th country with the highest suicide rate in the world and the 8th highest country in ASEAN. With suicides reaching 3.7 per 100,000 population. Data from the Indonesian National Commission for Child Protection, a mid-2012 report there were 20 cases of suicide children with the youngest age of 13 years [1]. The province with the highest child and adolescent suicide rates in Indonesia is the Special Region of Yogyakarta. Of the five districts in the province of Yogyakarta Special Region, Gunungkidul district is the highest contributor to suicide rates for five years in a row from 2013 to 2017. In 2017, data on suicide rates in Gunungkidul occurred in 26 cases [2].

Data from the District Health Office of Gunungkidul, in 2015 there were 33 suicides. Six of these cases occurred at the age of 15-30 years. The number of suicide attempts was 37 cases, eleven of them occurred at the age of 15-19 years. Of the 18 subdistricts in Gunungkidul district, Semin sub-district is the district with the highest suicide attempt at the age of 15-19 years in 2015, as many as nine cases [3].

According to Kaplan and Sadock (2014) [4] one of the highest suicide rates is in adolescents, which increases to an alarming rate and is the second leading cause of death in adolescents. This fact is related to the sharp increase in depression rates in adolescents. Depression can occur at any age, from children, teenagers to old age. The prevalence of depression increases during adolescence. On average each year is close to 
9\% of children aged 12-17 years having at least one episode of depression [5]. One of the tasks of adolescent development is psychosocial development which is the search for identity in adolescents. Erikson in Potter \& Perry (2010) [6] reviewed the confusion of identity or role as the main danger at this level, group rejection in adolescent members is a defence mechanism against identity confusion.

Spirituality as the innermost and essential part of an individual has an important role related to emotions or behaviour. As social and religious beings, spiritual emptiness will lead to psychosocial problems in life that will ultimately make individuals commit suicide as a shortcut to solve problems [7]. Thus, the spiritual aspect in man will determine how he sees things in life and determine what steps will be taken to deal with life. The purpose of this study was to analyze spirituality and depression with suicidal tendencies in adolescents in Gunungkidul, Yogyakarta.

\section{RESEARCH METHODS}

This type of research uses quantitative research. The design used is descriptive correlational. The population in this study were high school and vocational high school students in the Gunungkidul Yogyakarta subdistrict, amounting to 988 students. The number of samples was 301 sampling techniques using purposive sampling. With inclusion criteria: students aged 15-24 years, not being treated in hospital. When the research was conducted in 12 months. Data collection techniques used in this study to capture data about Spirituality Spiritual Involvement and Beliefs Scale (SIBS), depression was measured using the Beck Depression Inventory-II questionnaire with 21 statements obtained from the Harcourt Psychological Corporation of San Antonio (1996). Depression levels of students will be expressed in several categories, namely: No depression $1=0-13$, mild depression $=14-19$, moderate depression $=20-28$, severe depression $=29-63$. Suicidal tendency uses a mini suicide prediction questionnaire plus 5.0.0. Secondary data in this study were obtained from the Gunung Kidul Regency Education Office. Data processing includes four stages, namely: Editing, Coding, Tabulating, Data Entry. Data analysis methods with univariate analysis and multivariate analysis Multivariate analysis Multiple regression / PLUM-ordinal Regression with the formula $\mathrm{Y}=\mathrm{a}+\mathrm{b} 1 \mathrm{X} 1+\mathrm{b} 2 \mathrm{X} 2[8]$.

\section{RESULTS AND DISCUSSION}

Health is one of the most important aspects to consider for each individual and by all parties. According to WHO (1948, in Taylor, 2011) [9] healthy is "a complete state of physical, mental, and social well-being and not merely the absence of disease or infirmity". Based on the definition of health, health is not only assessed from the presence or absence of a person's physical illness but is a physical-mental condition and social welfare that is lacking in none. Mentally unhealthy can be caused by various factors, such as biological, social, and psychological [9]. Based on various studies that take into account the role of the spiritual dimension in relation to health, it was found that health and successful promotion of mental health must involve dynamic interactions of the biological, psychological, social and spiritual domains (Cacioppo et al, 2000; Cacioppo, \& Berntson, 2007; Hatala, 2011 in Hatala, 2013) [10]. Therefore, it can be interpreted that spiritual is one of the important factors in improving the welfare of an individual's life [11]. Spirituality refers to personal experience or seeking the 
highest / transcendent reality that is not necessarily institutionally connected [12]. The results of the Wald analysis test and the significance value of the Spirituality variable were 0.111 and $p=0.739$. this shows that there is no meaningful relationship between charisma and suicidal tendencies among adolescents at Gunungkidul Yogyakarta Semin. This is consistent with previous research which shows that spirituality has a relationship that is not consistent with mental health or depression [13].

Youth spirituality at Gunungkidul Semin in the Medium category is 219 teenagers $(72.8 \%)$. It can be understood that a person's spiritual development will improve with age. It can be seen the age of the majority of respondents in the age range of 16-18 years as many as 234 people (77.7\%), this can be understood that adolescents also began to have an increase in abstract thinking. This increase in abstract thinking makes teens consider various ideas about religious and spiritual concepts. Besides that, the idealistic way of thinking in adolescents is increasing the basis of whether religion can provide the best way to a more ideal world than before. This increase in adolescent logical reasoning provides the ability to develop hypotheses and systematically see various answers to spiritual questions. [14] although statistically spiritual does not have a significant or insignificant relationship with suicidal tendencies it does not mean that spirituality can be ignored in life especially in adolescents. Because spirituality is the most important part of an individual's life that is related to emotions or behaviour. As social and religious beings believe in the presence of the Almighty, this spiritual emptiness will cause a person to become disoriented and psychosocial problems arise which can ultimately cause someone to commit suicide.

Religious support is known to inhibit individuals who have suicidal ideation and increase their life expectancy [15]. This means that there are risk factors related to spirituality that can lead to the idea of suicide in an individual. The religious aspect is one aspect that really needs to be considered and special implementation is needed in this regard in overcoming the depression that results in the risk of suicidal behaviour in individuals.

The lives of adolescents who are still in the development stage do not have a handle (anchor) in their lives. This is because teenagers are looking for their true identity. A teenager will make the handle of his life to maintain stability and achieve balance in his life. The most abstract anchor is God. The Anchor of God cannot be imagined so that it can only be observed from manifestations in the form of virtues or principles of life. Through these virtues, individuals can live the meaning of the anchor of God [16]. Adolescent living conditions filled with changes, demands, uncertainties and hopes make events in his life will be interpreted subjectively. These subjective differences are called individual differences. The difference depends on how the individual perceives according to his anchor [16]. Teenagers also do not yet have a complete grip, especially in terms of spirituality and religiosity because they are in the stage of individuation-reflective faith [17].

Depression variable has a Wald value of 21,839 and a significance value of $\mathrm{p}=$ 0,000 ( $p$ <0.05), this shows that depression affects the suicidal tendencies in adolescents. Individuals who commit suicide can not be separated from the factors that cause the idea of suicide appears. The factors that often cause an individual to have suicidal ideas vary greatly. There is a significant relationship between life expectancy and reason and the risk of suicidal behaviour. Low expectations and reasons for a person's life will allow the individual to become depressed and commit suicide [18]. 
Depression is widespread throughout the world. Depressive is a mental health disorder that has a huge impact on a person's ability to function at work, in dealing with others, and in other fields of life. The World Health Organization projects in 2020 that depression will be the second most debilitating condition and cardiovascular disease will cause more disability [19]. Depression not only affects the ability to function and quality of life but also physical health and encourage people to commit suicide (more than 1 million people/year worldwide) or change the important physiological processes needed to survive (immune, endocrine, and cardiovascular functions) [20].

Indonesia is a country that has a high prevalence of suicide. The World Health Organization (WHO) revealed in 2017 in Southeast Asia, especially in Indonesia the suicide rate reached 7,355 or 0.44 per cent of the total deaths. Three out of one hundred thousand deaths are said to have resulted from suicide and ranked Indonesia as 172nd in the world [21]. Suicide is committed by those who have a productive age, 15-29 years. Generally, individuals who have suicidal ideation have problems that they cannot resolve properly. The reason for committing suicide is based on several factors such as the high population of productive age, which makes life competition so intense and closely related to economic problems. Being trapped in pain and emotionality is one of the symptoms in individuals who have suicidal ideation, and this is the main target of interventions that need attention [22].

There are several ideas related to suicidal behavior. Some of these ideas / themes include factors that lead to the idea of suicide, suicidal experiences of the closest people, support of religious experts towards the risk of suicide, and psycho-religious interventions [23]. Judging from the demographics of the research site, Semin is a mountainous area, still upholding culture and myth that is detrimental to the "Pulung Hanging" which is a kind of light that when it appears and falls in one house there will be death. This according to the researchers also contributed to the tendency of suicide. Because these things can cause a person to become stressed, it is found in adolescents who have a tendency to respond to stress based on their situation and condition at that moment. Because they still lack experience in putting things into perspective, they tend to look at things that are more trivial. Stress that lasts a long time and continues to be a pressure in someone who will make someone become depressed. In addition to the demographic conditions and the lack of access of adolescents to conduct examinations or health consultations, especially mental disorders to health services that are lacking, causing adolescents can not know the problem and how to overcome the problems being experienced. Also because there are people closest or those around him who solve the problem by ending in suicide, so teenagers imitate it.

Suicide itself in which there are stages of suicide ideas. The idea of suicide is a process of contemplation of the concept of suicide or a process that is passed without taking action or action, where a person will not express his thoughts for suicide if not suppressed [24]. More than $90 \%$ of people who commit suicide suffer psychological disorders. [25] Psychological disorders that often accompany suicide include depression, alcohol abuse, schizophrenic disorder, bipolar disorder, feelings of helplessness, behaviour disorder, and psychosis [26].

The results showed depression categories in adolescents at Semin Gunungkidul in the category of No depression as many as 196 adolescents (65.1\%), mild as many as 67 adolescents (67\%), as many as 34 adolescents (11.3\%), Weight as much as 4 adolescents $(1.3 \%)$. While data on the tendency of suicide found no category as many as 263 adolescents (87.4\%), low as many as 27 adolescents (9.0\%), as many as 6 
adolescents $(2.0 \%)$, as high as 5 adolescents $(1.7 \%)$. This is consistent with previous studies conducted by Paltzer \& Pengpid, S (2017) in adolescents aged 13-15 years in ASEAN, 2007-2013, showing that adolescents in ASEAN countries have lower suicidal thoughts compared to developing countries and developed countries, where Indonesia itself is a country in ASEAN whose adolescents have low suicidal thoughts (4.2\%), although these results are still higher than Myanmar (1.1\%) [27]. However, this relatively low number does not mean this is not a problem. Suicidal tendencies or suicidal thoughts in someone must be watched out for. This is consistent with what is said by Matta (2016) that suicidal thoughts in adolescents in Indonesia tend to be low (4.2\%) compared to other ASEAN countries, this should be a concern. Moreover, mental health awareness in Indonesia is still relatively low [28]. In this study, there can be a number of things that cause suicidal tendencies in adolescents, namely Depression, harmful myths, spirituality, lack of access to health services, suicide experience of the closest person, religious expert support for suicide risk, and psycho-intervention religious.

\section{CONCLUSION}

The results of the study concluded that based on the statistical test of the hypothesis, it was found that Wald and the significance value in Spiritual variables were 0.111 and $p=0.739$ which showed that spirituality had no effect on suicidal tendencies in adolescents at Gunungkidul Yogyakarta Semin, while Depression Variables were 21,839 and $\mathrm{p}=0,000(\mathrm{p}<0.05)$, this shows that depressive factors influence suicidal tendencies in adolescents. However, even though spirituality does not statistically affect suicidal tendencies, it remains that in human life as social creatures will not be separated from spirituality as a basis and guidelines for humans or individuals to behave and behave in life.

\section{REFERENCES}

Anonim. 2018 by Universitas Psikologi) Sumber Artikel: https://www.universitaspsikologi.com/2018/06/perkembangan-diri-sosioemosispiritual-remaja-menurut-ahli.html

Aulia, Nur, (2016). Analisis Hubungan Faktor Resiko Bunuh Diri Dengan Ide Bunuh Diri Pada Remaja Di Ota Rengat Kab. Indragiri Hulu Tahun 2016. Fakultas Keperawtan Universitas Andalas.Tidak Dipublikasikan, Diakses 31 januari 2017, <http://scholar.unand. ac.id/131 54/5/Tesis\%201.engkap\%20Aulia.pdt>.

Balbuena, L \& Baetz M \& Bowen R (2013). Religious Attendance, Spirituality, and Mayor Depression in Canada: A 14 Year Follw-Up Study. The Canadian journal of Psychiatry, Vol 58,No 4, April 2013 W 225. CanJ Psychiatry 2013;58(4):225232.https://journals.sagepub.com/doi/10.1177/070674371305800408

Captain, C. (2008). Assessing suicide risk, Nursing made incredibly easy,6: p 46-53

C. Murray and A. Lopez, The Global Burden of Disease, Harvard University Press, Cambridge, Mass, USA, 1996.

DetikNews. https://news.detik.com/jawatengah/3636864/ angka-bunuh-diri-digunungkidul-tinggi-selama-2017-terjadi-26-kasus. Senin11September(2017)

Dew, RE, Daniel, SS, Goldston, DB, McCall, WV, Kuchibhatla,M., Schleifer, C., ... Koenig, HG (2010). Sebuah studi prospektif agama / spiritualitas dan gejala depresi 
di kalangan remaja pasien kejiwaan. Journal of Affective Disorders, 120 (1-3), 149157.

Durand, V.M., \& Barlow, D.H. (2003). Essentials of Abnormal Psychology (3rded.). USA: WadsworthThompson Learning. Inc.

Ghozali, I. (2011). Aplikasi Analisis Multivariate Dengan program IBM SPSS 19. Edisi 5. Semarang: Badan Penerbit Universitas Diponegoro

Harian Nasional. 2019. Diunduh 20 Januari 2019, pukul 15.15 WIB. http://www.harnas.co/2018/11/11/gangguanjiwa-rentan-picu-bunuh-diri

Hatala, Andrew R. (2013). Towards a biopsychosocial-spiritual approach in health psychology: Exploring theoretical orientations and future directions, Journal of Spirituality in Mental Health, 15:4, 256-276, doi: 10.1080/19349637.2013.776448.

Julianto, V \& Subandi (2015). Membaca Al Fatihah Reflektif Intuitif untuk Menurunkan Depresi dan Meningkatkan Imunitas. Jurnal Psikologi. Vol. 42 No. 1 April 2015: $34-46$

Kaplan dan Sadock., (2014) .Buku Ajar Psikiatri Klinis Edisi 2. Jakarta. EGC.

Khatimah,K.(2017). Studi Kualitatif Gambaran Self-Injury Di Fakultas Psikologi Universitas Padjajaran. http://pustaka.unpad.ac.id/wpcontent/uploads/ 2017/02/Khusnul-Khatimah.pdf. Diakses tgl 02 September 2019.

Lawrence, R.E., Brent, D., Mann, J.J., Burke, A.K., Grunebaum, M.F., Galfalvy, H.C., Oquendo, M.A., 2016a. Religion as a Risk Factor for Suicide Attempt and Suicide Ideation Among Depressed Patients: J. Nerv. Ment. Dis. 204, 845-850. https://doi.org/10.1097/NMD.00000000000 00484

Li, S., Yaseen, Z.S., Kim, H.-J., Briggs, J., Duffy, M., Frechette-Hagan, A., Cohen, L.J., Galynker, I.I., 2018. Entrapment as a mediator of suicide crises. BMC Psychiatry 18. https://doi.org/10.1186/s12888-018-1587-0

Litaqia, W \& Permana I. (2019). Peran Spiritualita Dalam Mempengaruhi Resiko Perilaku Bunuh Diri: A Literature Review. Jurnal Keperawatan Respati Yogyakarta, 6(2), Mei 2019, 615-624.

Luo, X., Wang, Q., Wang, X., Cai, T., 2016. Reasons for living and hope as the protective factors against suicidality in Chinese patients with depression: a cross sectional study. BMC Psychiatry 16. https://doi.org/10.1186/s12888-016-0960-0

Matta, A. (2016, Desember 13). Kesehatan Mental di Indonesia Hari Ini. Retrieved Januari 18, 2019, from Tirto: https://tirto.id/kesehatan-mental-di-indonesia-hari-inib9twDavison, R.M. (2001) GSS and action research in the Hong Kong Police. Information Technology and People, 14, 60-7

Nazri Rizki Annistia,(2016). Hubungan Antara Spiritualitas dengan Kecenderungan Bunuh Diri pada Orang Dewasa Awal di Kabupaten Gunung Kidul. https://digilib.uns.ac.id/dokumen/detail/54780/Hubungan-Antara-Spiritualitasdengan-Kecenderungan-Bunuh-Diri-pada-Orang-Dewasa-Awal-di-KabupatenGunung-Kidul

Papalia, dkk. 2014. Menyelami Perkembangan Manusia: Experience Human Development. Jakarta: Salemba Humanika

Peltzer, K., \& Pengpid, S. (2017). Suicidal ideation and associated factors among students aged 13-15 years in Association of Southeast Asian Nations (ASEAN) member states, 2007-2013. International Journal of Psychiatry in Clinical Practice . repository.hsrc.ac.za/handle/20.500.11910/10813?show=full

Potter \& Perry. 2010. Fundamental Keperawatan Buku 1 Edisi 7. Jakarta: Salemba Medika 
Rahmatusakdiah, Siti, (2016). Hubungan Kecerdasan Spiritual Dengan Ide Bunuh Diri Pada Remaja di SMA Gunungkidul. STIKes Surya Global, Tidak dipublikasikan.

Riyono, B. (2012). Motivasi dengan perspektif psikologi islam. Sleman: Quality Publishing

Suryani, L.K., \& Lesmana, C.B.J. (2008). Hidup Bahagia: Perjuangan Melawan Kegelapan. Jakarta: Pustaka Obor Populer

Taylor, Shelley E. (2011). Health psychology, 8th edition. U.S.A: McGraw-Hill, Inc.

World Health Organization, Suicide Prevention (SUPRE), World Health Organization,

Geneva,

Switzerland,

2009 ,

http://www.who.int/mental

health/prevention/suicide/suicide prevent/en/index.html. 